Quantitative trait loci with sex-specific effects for internal organs weights and hematocrit value in a broiler-layer cross

A. S. A. M. T. Moura, M. C. Ledur, C. Boschiero, K. Nones, L. F. B. Pinto, F. R. F. Jaenisch, D. W. Burt \& L. L. Coutinho

Journal of Applied Genetics Microorganisms and Organelles

ISSN 1234-1983

J Appl Genetics

DOI 10.1007/s13353-015-0325-2

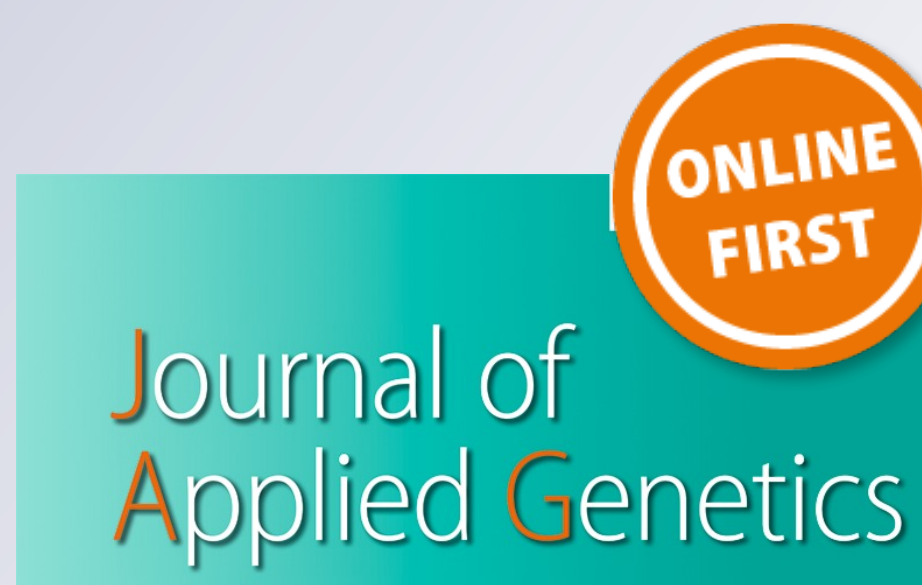

Approved by

The Polish Genetic Society

The Polish Society of Human Genetics

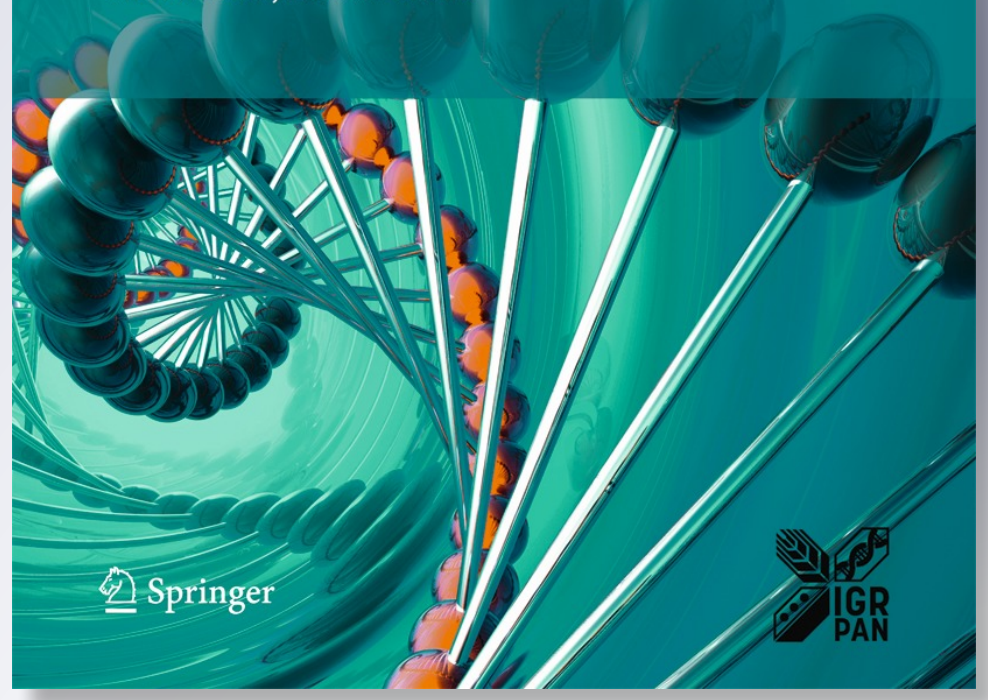

照 Springer 
Your article is protected by copyright and all rights are held exclusively by Institute of Plant Genetics, Polish Academy of Sciences, Poznan. This e-offprint is for personal use only and shall not be self-archived in electronic repositories. If you wish to self-archive your article, please use the accepted manuscript version for posting on your own website. You may further deposit the accepted manuscript version in any repository, provided it is only made publicly available 12 months after official publication or later and provided acknowledgement is given to the original source of publication and a link is inserted to the published article on Springer's website. The link must be accompanied by the following text: "The final publication is available at link.springer.com". 


\title{
Quantitative trait loci with sex-specific effects for internal organs weights and hematocrit value in a broiler-layer cross
}

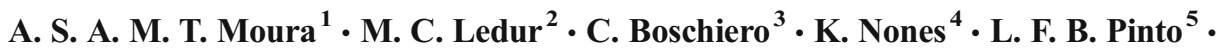 \\ F. R. F. Jaenisch ${ }^{2}$ D. W. Burt ${ }^{6}$ L. L. Coutinho ${ }^{3}$
}

Received: 12 August 2015 / Revised: 22 September 2015 / Accepted: 14 October 2015

(C) Institute of Plant Genetics, Polish Academy of Sciences, Poznan 2015

\begin{abstract}
Rapid growth in broilers is associated with susceptibility to metabolic disorders such as pulmonary hypertension syndrome (ascites) and sudden death. This study describes a genome search for QTL associated with relative weight of cardio respiratory and metabolically important organs (heart, lungs, liver and gizzard), and hematocrit value in a Brazilian broiler-layer cross. QTL with similar or different effects across sexes were investigated. At 42 days of age after fasted for $6 \mathrm{~h}$, the $F_{2}$ chickens were weighed and slaughtered. Weights and percentages of the weight relative to BW42 of gizzard, heart, lungs, liver and hematocrit were used in the QTL search. Parental, $\mathrm{F}_{1}$ and $\mathrm{F}_{2}$ individuals were genotyped with 128 genetic markers (127 microsatellites and 1 SNP) covering 22 linkage groups. QTL mapping analyses were carried out using mixed models. A total of 11 genome-wide significant QTL and five suggestive linkages were mapped. Thus, genomewide significant QTL with similar effects across sexes were
\end{abstract}

Communicated by: Maciej Szydlowski

A. S. A. M. T. Moura

anamoura@fmvz.unesp.br

1 Departamento de Produção Animal, Universidade Estadual Paulista UNESP/FMVZ, Botucatu, SP 18618-970, Brazil

2 Embrapa Suínos e Aves, C.P. 21, Concórdia, SC 89700-000, Brazil

3 Departamento de Zootecnia, USP/ESALQ, C.P. 09, Piracicaba, SP 13418-900, Brazil

4 QIMR Berghofer Medical Research Istitute, 300 Herston Road, Brisbane, QLD 4006, Australia

5 Departamento de Zootecnia, Universidade Federal da Bahia, Salvador, BA, Brazil

6 Division of Genetics and Genomics, The Roslin Institute and Royal (Dick) School of Veterinary Studies, University of Edinburgh, Midlothian EH25 9PS, UK mapped to GGA2, 4 and 14 for heart weight, and to GGA2, 8 and 12 for gizzard \%. Additionally, five genome-wide significant QTL with different effects across sexes were mapped to GGA 8, 19 and 26 for heart weight; GGA26 for heart $\%$ and GGA3 for hematocrit value. Five QTL were detected in chromosomal regions where QTL for similar traits were previously mapped in other $F_{2}$ chicken populations. Seven novel genome-wide significant QTL are reported here, and 21 positional candidate genes in QTL regions were identified.

Keywords Candidate gene · Gizzard · Heart · Liver · Microsatellite marker

\section{Introduction}

Rapid growth in broilers is associated with susceptibility to metabolic disorders such as pulmonary hypertension syndrome (ascites) and sudden death. In broilers, muscle development is proportionally greater than that of important internal organs, in particular the heart and lungs. Rapid growth requires high metabolic rate, which generates high oxygen demand. Insufficient pulmonary vascular capacity and inability to deliver enough oxygen to meet the metabolic demand triggers a cascade of events including high cardiac output and increasing blood flow to the lungs causing pulmonary hypertension and accumulation of fluid in the celomic cavity (ascites) followed by death (Jaenisch et al. 2001; Druyan 2012).

Hypoxemia in ascites susceptible broilers lead to a series of symptoms that include increased hematocrit, heart weight and right ventricle to total ventricle ratio (Luger et al. 2001; Druyan 2012). There is an indication that increased hematocrit in ascitic chickens results from enhanced, but defective 
erythropoiesis, leading to significant increase in immature erythrocytes (Luger et al. 2003).

Environmental factors that induce high oxygen consumption, such as low temperatures, and low oxygen supply at high altitudes, were reported to be involved in ascites incidence, but there is an experimental evidence for an important additive genetic component in susceptibility to ascites (Moghadam et al. 2001). Heritability estimates ranging from 0.1 to 0.7 were reported, in addition to differences among chicken breeds and genders. Fast growing males were found to be much more susceptible to ascites than females (Moghadam et al. 2001). The rapid success of selection experiments for ascites resistance (Wideman and French 2000) as well as the development of susceptible and resistant chicken lines by applying divergent selection for ascites mortality (Druyan et al. 2007; Pavlidis et al. 2007) indicated that a few major genes were involved in the genetic control of susceptibility to ascites.

Sudden death is an acute heart process associated with defibrillation of the right ventricle (Jaenisch et al. 2001). Incidence of ascites and sudden death represents important economic losses in the poultry industry, including mortality near to the end of the growing period and transportation, or leading to condemnation of carcasses in the slaughter house. Management practices adopted to reduce growth rate, also reduced oxygen demand and mortality rate in commercial flocks. However, this approach may compromise performance and the efficiency of broiler production (Druyan 2012). Finding new chromosomal regions associated with weight variation of cardio respiratory organs and the hematocrit value may provide breeders with tools to select against metabolic disorders in fast growing chickens.

Quantitative trait loci (QTL) mapping is the first step for finding genomic regions associated with quantitative traits. However, only a few studies have mapped QTL for heart (Rabie et al. 2005; Zhou et al. 2006) and lungs related traits (Nones et al. 2006; Park et al. 2006), and for the hematocrit value (Navarro et al. 2005; Pinard-van der Laan et al. 2009), in independent populations, according to the Chicken QTL Database (www.animalgenome.org/cgi-bin/QTLdb/GG/ index). Two candidate genes in GGA9 (AGTR1 and UTS2D) were recently associated with susceptibility to ascites and ventricular hypertrophy in an $F_{2}$ cross between ascites-susceptible and resistant lines (Krishnamoorthy et al. 2014).

This study describes a whole genome search for QTL associated with relative weight of cardiorespiratory and metabolically important organs (heart, lungs, liver and gizzard) and hematocrit value in a Brazilian broiler-layer cross. Due to differences in metabolism between males and females, QTL with similar or different effects across sexes were also considered. Positional candidate genes were identified in QTL regions.

\section{Material and methods}

\section{Experimental population and trait recording}

The $F_{2}$ population used in this study originated from a wide cross between a broiler (TT) and a layer line (CC). These lines were selected at Embrapa Swine and Poultry, Concórdia, Brazil. When reared as broilers, they showed a fivefold difference in body weight at 41 days of age (Ledur et al. 2000). In the parental generation, seven TT males were mated to seven CC females to produce the $F_{1}$ generation. Twenty one $F_{1}$ females were then artificially inseminated with semen from seven $F_{1}$ males in a 3:1 ratio to produce the $F_{2}$ generation. The latter comprised seven paternal half-sib families composed of three full-sib families of approximately 100 individuals each, produced over 17 hatches, summing up to $2063 \mathrm{~F}_{2}$ individuals.

The $F_{2}$ chickens were reared as broilers in floor pens up to 35 days of age when they were individually caged up to 41 days. At 42 days of age, after fasted for $6 \mathrm{~h}$, they were transported to the slaughter house, weighed (BW42) and slaughtered. Weights of gizzard, heart, lungs and liver were recorded (in grams) immediately after slaughter. The covariate BW42 was used in the QTL mapping analyses of organs weights. Percentages of the weight of these organs relative to BW42 were calculated and also used in the QTL search. Body weight $(+21.4 \%)$ and hematocrit value were higher in males than in females, but gizzard \% was higher in females (Table 1).

Blood samples were collected at slaughter for DNA analysis and hematocrit value determination by the microhematocrit method (Cardoso and Tessari 2003).

\section{QTL mapping analyses}

Parental ( $n=12), F_{1}(n=10)$ and $F_{2}$ (up to 649) individuals from five to six full-sib families were genotyped with 127 microsatellite markers and one SNP covering 22 linkage groups (GGA1 to $15,18,19,23,24,26$ to 28 ). Total map length was $2630 \mathrm{cM}$, corresponding to approximately $63 \%$ of genome coverage. For more details on genotyping and linkage map construction, refer to Ambo et al. (2009) and Campos et al. (2009).

Quantitative trait loci mapping analyses were carried out using mixed models implemented in the Qxpak software (Pérez-Enciso and Misztal 2004) according to the following model:

$y_{i j k}=u+S_{i}+H_{j}+\mathrm{b}_{\mathrm{ijk}} B W_{42}+c_{i j k} I_{k}+a_{i j k} A+\mathrm{d}_{\mathrm{ijk}} D_{k}+e_{i j k}$,

where $y$ is the phenotype, $u$ is the general mean, $S_{i}$ is the fixed effect of sex, $H_{j}$ is the fixed effect of hatch, $b$ is the coefficient corresponding to the covariate BW42, $\mathrm{c}_{\mathrm{ijk}}$ is the coefficient associated with the infinitesimal random animal genetic effect, $a_{i j k}$ is the coefficient associated with the 
Table 1 Descriptive statistics of traits used in QTL mapping

\begin{tabular}{|c|c|c|c|c|c|c|c|}
\hline Trait & Sex & $\mathrm{N}$ & Mean & $\mathrm{SD}^{\mathrm{a}}$ & Minimum & Maximum & $\mathrm{CV}^{\mathrm{b}}$ \\
\hline \multirow[t]{2}{*}{ BW42 } & M & 539 & 1094.09 & 157.55 & 627.00 & 1688.00 & 14.40 \\
\hline & $\mathrm{F}$ & 527 & 901.19 & 141.16 & 402.00 & 1370.00 & 15.66 \\
\hline \multirow[t]{2}{*}{ Liver weight } & M & 539 & 29.17 & 4.58 & 20.00 & 49.00 & 15.71 \\
\hline & $\mathrm{F}$ & 526 & 23.94 & 3.84 & 15.00 & 38.00 & 16.03 \\
\hline \multirow[t]{2}{*}{ Heart weight } & M & 539 & 7.24 & 1.54 & 3.00 & 15.00 & 21.23 \\
\hline & $\mathrm{F}$ & 525 & 5.84 & 1.38 & 2.00 & 10.00 & 23.61 \\
\hline \multirow[t]{2}{*}{ Gizzard weight } & M & 539 & 26.51 & 4.48 & 16.00 & 43.00 & 16.89 \\
\hline & $\mathrm{F}$ & 526 & 23.20 & 3.82 & 13.00 & 35.00 & 16.44 \\
\hline \multirow[t]{2}{*}{ Lungs weight } & M & 538 & 9.20 & 2.27 & 3.00 & 16.00 & 24.64 \\
\hline & $\mathrm{F}$ & 526 & 7.19 & 1.79 & 3.00 & 13.00 & 24.84 \\
\hline \multirow[t]{2}{*}{ Hematocrit \% } & M & 532 & 28.06 & 2.75 & 18.00 & 42.00 & 9.81 \\
\hline & $\mathrm{F}$ & 516 & 27.92 & 2.93 & 16.00 & 44.00 & 10.48 \\
\hline \multirow[t]{2}{*}{ Liver $\%{ }^{c}$} & M & 539 & 2.68 & 0.34 & 1.84 & 4.68 & 12.71 \\
\hline & $\mathrm{F}$ & 526 & 2.68 & 0.38 & 1.83 & 7.71 & 14.12 \\
\hline \multirow[t]{2}{*}{ Heart $\%{ }^{c}$} & M & 539 & 0.66 & 0.12 & 0.28 & 1.28 & 18.21 \\
\hline & $\mathrm{F}$ & 525 & 0.65 & 0.13 & 0.32 & 1.20 & 20.60 \\
\hline \multirow[t]{2}{*}{ Gizzard $\%^{c}$} & M & 539 & 2.44 & 0.39 & 1.50 & 3.71 & 15.93 \\
\hline & $\mathrm{F}$ & 526 & 2.60 & 0.39 & 1.73 & 3.73 & 14.86 \\
\hline \multirow[t]{2}{*}{ Lungs $\%^{c}$} & M & 538 & 0.84 & 0.17 & 0.28 & 1.36 & 19.88 \\
\hline & $\mathrm{F}$ & 526 & 0.80 & 0.17 & 0.29 & 1.39 & 21.11 \\
\hline
\end{tabular}

${ }^{\text {a }} \mathrm{SD}=$ standard deviation

${ }^{\mathrm{b}} \mathrm{CV}=$ coefficient of variation

${ }^{c}$ Organs percentages relative to body weight at 42 days additive effect (A) of the QTL, $\mathrm{d}_{\mathrm{ijk}}$ is the coefficient associated with the dominance effect (D) of the QTL and $e_{i j k}$ is the random residue. The model that considers QTL with sex-specific effects can be written in a similar way, but an additive and a dominance effect were estimated for each sex separately. The covariate BW42 was included in the models for organ weight traits, but not for the analyses of traits measured as percentages of body weight.

The analyses were initiated by fitting a model with an additive effect to all the data (all $\mathrm{F}_{2}$ chickens included, irrespective of gender). If the statistical test for a QTL exceeded the suggestive threshold level, a second model with additive + dominance effect was fitted, otherwise the analyses were halted. This procedure was subsequently repeated for each sex separately. Additive and dominance effects were considered significant when they were at least twice the magnitude of their respective standard errors.

Significance thresholds were computed using 10,000 permutations (Churchill and Doerge 1994) for probability levels of 1 and $5 \%$ genome-wide and for suggestive linkage (Lander and Kruglyak 1995), calculated following the Bonferroni correction and considering a genome length of $4200 \mathrm{cM}$ (Schmid et al. 2005). Confidence intervals for QTL locations were obtained as described by Mangin et al. (1994). The method involves searching the first position, both to the right and to the left of the QTL location that has the likelihood ratio test, LRT $<\left(\mathrm{LRT}_{\text {maximum }}-\chi^{2}\right)$. For instance, in the present study $\chi^{2}=3.84$ for LRT with one degree of freedom. Therefore, if the significant position corresponds to a $\mathrm{LRT}_{\text {maximum }}=20$, then one would search for the first position, on both sides of the maximum point, that has LRT $<16.16$. The interval obtained in this way corresponds to the $95 \%$ confidence interval for the QTL.

According to Sorensen et al. (2003), the total phenotypic variance between the parental lines explained by the QTL can be expressed as:

$V P_{\exp }=2 p_{Q}\left(1-p_{Q}\right) a^{2}$,

where $p_{Q}$ is the frequency of the Q allele from the QTL, for which we assume the value 0.5 in the line-cross model, whereas $\alpha$ is the estimate for the additive effect of the QTL in the position in which it was mapped. From this information, the percent from total variance explained by the QTL may be estimated as follows:

$\% V P_{\exp }=\frac{V P_{\exp } * 100}{V P}$,

where $V P_{\exp }$ is the phenotypic variance explained by the QTL and $V P$ is the total phenotypic variance in the model that includes the effects of the QTL. 
Previous studies from our group reported QTL for performance, carcass and organs traits on GGA1 (Nones et al. 2006) and an association study of two SNPs (on IGFI and KDM5A genes) on GGA1 with organs traits and hematocrit value (Boschiero et al. 2013). For this reason, QTL for organs traits and hematocrit value on GGA1 are not presented in this study.

\section{Analysis of positional candidate genes}

In this study, we mapped QTL to marker intervals that ranged from 6.6 (GGA8) to $72.6 \mathrm{cM}$ (GGA26), therefore it was not possible to associate gene polymorphisms with traits under study. However, we explored seven genomic regions within marker intervals where QTL were mapped, searching for potential positional candidate genes with known biological functions, based on OMIM ${ }^{\circledR}$ (http://www.omin.org) and NCBI (http://www.ncbi.nlm.nih.gov/) databases, that could be related to the respective traits under study. Microsatellite positions were obtained from the last version of chicken reference sequence (Gallus_gallus_4.0) based on the ArkDB database (http://www.thearkdb.org/arkdb/). Exact positions of markers MCW0094 and ROS0314 were not available in the databases, therefore we blasted primer sequences to obtain their positions. Subsequently, the BioMart tool (www. biomart.org) was employed to obtain a list of genes for each marker interval to which a QTL had been mapped.

\section{Results and discussion}

This study describes a whole genome search for QTL associated with relative weight of cardiorespiratory and metabolically important organs (heart, lungs, liver and gizzard) and hematocrit value in a Brazilian broiler-layer cross. A total of 11 genome-wide significant QTL and five suggestive linkages were mapped. From these, six genome-wide significant QTL and five suggestive linkages showed similar effects across sexes and five genome-wide significant QTL had different effects across sexes.

Positional candidate genes were identified in marker intervals where QTL were mapped, except for gizzard weight and percentage. A total of 654 genes (BioMart Portal 2014) were mapped to seven intervals associated to QTLs. The number of genes in each interval is reported in Table 2. Positional candidates $(n=21)$ were selected based on current known biological functions.

\section{QTL with similar effects across sexes}

A total of six genome-wide significant QTL and five suggestive linkages with similar effects across sexes were mapped to GGA2, 3, 4, 8, 12 and 14 for organs weights and \% (Table 3). For relative heart weight, QTL exceeding $1 \%$ genome-wide threshold were mapped to GGA2, 4 and 14. Negative additive effects indicated that the QTL allele increasing the trait value came from the layer line in all three cases. This is not surprising considering that the broiler line was selected for fast growth and to increase muscle development, which may have reduced the relative proportion of internal organs, including the cardiorespiratory tract (Deeb and Lamont 2002).

The QTL on GGA2 was mapped to the MCW0185MCW0264 interval. Interestingly, the two most significant QTL mapped by Rabie et al. (2005) for right and total ventricular weight as percentage of body weight were located in this same marker interval. Those two traits were related to the susceptibility to develop pulmonary hypertension syndrome and the authors indicated two genes involved in early cardiogenesis as possible positional candidates in that marker interval: ZFPM2 and GATA6. Our search within this interval retrieved three other potential candidate genes, involved in cardiac development and function: DTNA, SNAI2 and CHD7 (Table 4). One non-synonymous SNP in the DTNA gene was identified in a human family with left ventricular noncompaction and congenital heart disease (Ichida et al. 2001). SNAI2 participates in Wnt signaling that was shown to restrict cardiomyocyte proliferation and control heart size in the mouse (Heallen et al. 2011). Vissers et al. (2004) found CHD7 mutations in individuals with CHARGE syndrome (congenital anomalies in humans including malformations of the heart). This gene is expressed in branchial arches of chicken embryos (Aramaki et al. 2007), which is the primordial tissue that give rise to the heart.

The QTL mapped for heart weight to GGA4 (LEI0085$M C W 0174$ interval) was in a similar region previously associated to heart weight in another broiler-layer cross (Zhou et al. 2006), close to $A D L 0260$, which is in the same chromosomal region as $L E I 0085$. These two markers map between 82 and $83 \mathrm{Mb}$. A candidate gene (WHSC1), which encodes a histone methyltransferase that regulates the expression of transcription factors in mammalian embryonic heart (Vallaster et al. 2012), was located at $82.8 \mathrm{Mb}$ (Table 4).

A novel QTL for heart weight is reported here on GGA14 (Table 4). A possible candidate gene in this region was $D N A J A 3$, which encodes a mitochondrial chaperone. Mice $D N A J A 3$ deficient developed dilated cardiomyopathy, died prematurely due to progressive respiratory chain deficiency and decreased copy number of mitochondrial DNA in cardiomyocytes (Hayashi et al. 2006).

For gizzard weight, three suggestive linkages were detected on GGA2, 4 and 8, whereas for gizzard \% three QTL were found on GGA2, 8 and 12 and a suggestive linkage on GGA3 (Table 3). QTLs for gizzard weight and percentage were mapped to the same interval on GGA8, had positive additive effects and are likely to be the same QTL. The QTL for gizzard $\%$ on GGA12 exceeded the $1 \%$ genome wide threshold and showed positive dominance effects, suggesting the 
Table 2 Genomic positions of markers from intervals where QTL were mapped

\begin{tabular}{|c|c|c|c|c|c|}
\hline Marker interval & GGA & Position gga $\left(\right.$ ArkDB) ${ }^{a}$ & Number of genes (Biomart) ${ }^{b}$ & $\begin{array}{l}\text { First marker } \\
\text { Blast position }\end{array}$ & $\begin{array}{l}\text { Second marker } \\
\text { Blast position }^{\mathrm{c}}\end{array}$ \\
\hline$M C W 0185-M C W 0264$ & 2 & $105,848,755-112,648,761$ & 66 & $105,848,938$ & $112,648,761$ \\
\hline MCW0040-LEI0166 & 3 & 103,716,571-Unknown & 71 & $103,716,571$ & $105,017,790$ \\
\hline LEIO085-MCW0174 & 4 & $82,437,148-84,297.286$ & 19 & $82,437,147$ & $84,297,286$ \\
\hline MCW0351-LEPR (LEPR-MCW0351) & 8 & $27,238,562(L E P R)-27,623,626$ & 14 & $27,238,562$ & $27,623,626$ \\
\hline$M C W 0123-A D L 0263$ & 14 & $11,341,581-13,932,426$ & 110 & $11,341,581$ & $13,932,425$ \\
\hline MCW0094-MCW0287 & 19 & Unknown-7,262,555 & 202 & $3,373,697$ & $7,262,555$ \\
\hline ROS0314-LEI0074 & 26 & Unknown-4.777.041 & 172 & $1,367,176$ & $4,776,827$ \\
\hline
\end{tabular}

${ }^{a}$ Position according to Ensembl (ENSEMBL71 Galgal4 Chick Assembly: 4)

b Ensembl version 71 database

c Position according to NCBI database

superiority of the heterozygote over the midparent. The other QTL for gizzard $\%$ on GGA2 and 8 exceeded the $5 \%$ genome-wide threshold and showed positive additive effects, indicating that the QTL allele that increased gizzard \% came from the broiler line. To our knowledge, no previous studies have mapped QTL for relative gizzard weight to any of these chromosomal regions; therefore, they are novel positions for this trait. No potential positional candidate genes with known biological function for gizzard weight or $\%$ were identified. A suggestive linkage was detected for liver \% in the LEI0098MCW0123 interval on GGA14, also a novel position for this trait.

The percentage of the phenotypic variance explained by the QTL with similar effects across sexes varied from 0.88 to $2.56 \%$ (Table 3). Six out of 11 QTL and suggestive linkages described in Table 3 were mapped to similar intervals that we previously associated with QTL for body weight (Ambo et al. 2009) and carcass traits (Baron et al. 2010). Examples of potential pleiotropic QTL is a QTL for breast \% mapped to GGA2 and a QTL for shank \% mapped to GGA4 in the same intervals to which QTL for heart weight were mapped in the present study. They are likely to be pleiotropic QTL with positive additive effects on percentage of breast and shank, but negative additive effects on heart weight.

\section{QTL with different effects across sexes}

A total of five genome-wide significant QTL with different effects across sexes were mapped to GGA3, 8, 19 and 26 (Table 5) for three traits. One QTL for relative heart weight

Table 3 Quantitative trait loci with sex-similar effects

\begin{tabular}{|c|c|c|c|c|c|c|c|c|c|}
\hline Trait & GGA & Position (cM) & $\begin{array}{l}\text { Confidence } \\
\text { interval }\end{array}$ & $\mathrm{LRT}^{\mathrm{a}}$ & Flanking markers & Model & Additive effect (SE) & $\begin{array}{l}\text { Dominance } \\
\text { effect (SE) }\end{array}$ & $\mathrm{PV}^{\mathrm{b}}(\%$ \\
\hline \multirow[t]{3}{*}{ Heart weight ${ }^{c}$} & 2 & 239 & $232-251$ & $17.75^{* *}$ & $\begin{array}{l}M C W 0185- \\
M C W 0264\end{array}$ & A & $-0.13(0.07)$ & & 1.68 \\
\hline & 4 & 168 & $158-177$ & $28.68 * *$ & LEI0085-MCW0174 & $\mathrm{AD}$ & $-0.33(0.14)$ & $-0.20(0.35)$ & 1.69 \\
\hline & 14 & 26 & $11-41$ & $20.83^{* *}$ & $M C W 0123-A D L 0263$ & A & $-0.31(0.10)$ & & 2.05 \\
\hline \multirow[t]{3}{*}{ Gizzard weight $^{\mathrm{c}}$} & 2 & 3 & $1-27$ & $14.92 \dagger$ & LMU0013-MCW0247 & $\mathrm{AD}$ & $0.54(0.20)$ & $-0.72(0.29)$ & 1.33 \\
\hline & 4 & 140 & $121-178$ & $13.89 \dagger$ & MCW0240-LEI0063 & A & $-1.55(0.39)$ & & 1.43 \\
\hline & 8 & 68 & $50-83$ & $13.24 \dagger$ & $A B R 0345-A D L 0172$ & A & $0.96(0.27)$ & & 1.04 \\
\hline \multirow[t]{4}{*}{ Gizzard (\%) } & 2 & 20 & $1-34$ & $18.42 *$ & MCW0247-LEI0086 & $\mathrm{AD}$ & $0.11(0.03)$ & $-0.07(0.05)$ & 1.84 \\
\hline & 3 & 46 & $1-76$ & $14.29 \dagger$ & $\begin{array}{l}M C W 0169- \\
M C W 0222\end{array}$ & A & $0.12(0.04)$ & & 0.88 \\
\hline & 8 & 60 & $41-77$ & $20.29 *$ & ABR0345-ADL0172 & A & $0.13(0.03)$ & & 1.44 \\
\hline & 12 & 86.2 & $75-86.2$ & $18.65^{* *}$ & ADL0044-GCT0055 & $\mathrm{AD}$ & $-0.06(0.03)$ & $0.21(0.05)$ & 2.56 \\
\hline Liver (\%) & 14 & 13 & $1-39$ & $10.12 \dagger$ & LEI0098-MCW0123 & A & $-1.33(0.37)$ & & 1.08 \\
\hline
\end{tabular}

${ }^{\text {a }}$ LRT =likelihood ratio test; $\uparrow$ suggestive genome-wide; *5 \% genome-wide; **1\% genome-wide

${ }^{\mathrm{b}} \mathrm{PV}(\%)=$ percentage of the phenotypic variance explained by the QTL

${ }^{c}$ Body weight at 42 days was used as covariate in the analyses of these traits 
Table 4 Positional candidate genes identified in the QTL regions

\begin{tabular}{|c|c|c|c|c|c|}
\hline Trait $^{\mathrm{a}}$ & GGA & Flanking markers ${ }^{\mathrm{b}}$ & Candidate gene $^{1}$ & Description & Gene function in humans or model organism ${ }^{\mathrm{c}}$ \\
\hline \multirow{20}{*}{$\begin{array}{l}\text { Heart weight } \\
\text { and } \%\end{array}$} & \multirow[t]{3}{*}{2} & \multirow{3}{*}{$\begin{array}{l}M C W 0185-M C W 0264 \\
\quad(105.8-112.6)\end{array}$} & DTNA (107.1) & Dystrobrevin alfa & Congenital heart defects \\
\hline & & & SNAI2 (108.1) & SNAIL, Drosophila homolog of & $\begin{array}{l}\text { Cardiomyocyte proliferation and } \\
\text { controls heart size }\end{array}$ \\
\hline & & & CHD7 (112.6) & $\begin{array}{l}\text { Chromodomain helicase DNA- } \\
\text { binding protein } 7\end{array}$ & Cardiovascular malformations \\
\hline & 4 & $\begin{array}{l}\text { LEIO085-MCW0174 } \\
\quad(82.4-84.3)\end{array}$ & WHSC1 (82.8) & WHS candidate 1 gene & $\begin{array}{l}\text { Histone methyltransferase, regulates the } \\
\text { expression of transcription factors in } \\
\text { embryonic heart }\end{array}$ \\
\hline & 8 & $\begin{array}{l}M C W 0351-L E P R \\
\quad(27.2-27.6)\end{array}$ & $\operatorname{LEPR}(27.2)$ & Leptin receptor & Cardiac signal transduction pathway \\
\hline & 14 & $\begin{array}{l}M C W 0123-A D L 0263 \\
\quad(11.3-13.9)\end{array}$ & DNAJA3 (12.7) & $\begin{array}{l}\text { DNAJ/HSP40 homolog, subfamily } \\
\text { A, member } 3\end{array}$ & $\begin{array}{l}\text { Mitochondrial chaperone involved in } \\
\text { dilated cardiomiopathy }\end{array}$ \\
\hline & \multirow[t]{8}{*}{19} & \multirow[t]{8}{*}{$\begin{array}{l}M C W 0094-M C W 0287 \\
\quad(3.4-7.3)\end{array}$} & $M Y L 2(3.8)$ & $\begin{array}{l}\text { Myosin light chain 2, regulatory, } \\
\text { cardiac, slow }\end{array}$ & Cardiac muscle contraction \\
\hline & & & $Y W H A G(4.2)$ & $\begin{array}{l}\text { tyrosine 3-monooxygenase/ } \\
\text { tryptophan 5-monooxygenase } \\
\text { activation protein, gamma isoform }\end{array}$ & Hypertrophic cardiomyopathy \\
\hline & & & RASL10B (4.4) & Ras-like family 10, member B; & $\begin{array}{l}\text { Regulates atrial natriuretic peptide secretion } \\
\text { from atrial cardiomyocytes }\end{array}$ \\
\hline & & & $U N C 45 B(4.5)$ & UNC45, C. elegans homolog of, B & $\begin{array}{l}\text { Myoblast fusion and sarcomere formation in } \\
\text { heart muscle }\end{array}$ \\
\hline & & & $N E K 8(5.8)$ & Never in mitosis gene A-related kinase 8 & Renal and cardiovascular development \\
\hline & & & SLC6A4 (6.2) & $\begin{array}{l}\text { Solute carrier family } 6 \text { neurotransmitter } \\
\text { transporter, serotonin), member } 4\end{array}$ & Negative regulation of organ growth \\
\hline & & & $P I G L(6.5)$ & Phosphatidylinositol glycan, class L & Congenital heart defects \\
\hline & & & $A K A P 10(6.8)$ & A-kinase anchor protein 10 & Susceptibility to cardiac conduction defect \\
\hline & \multirow[t]{6}{*}{26} & \multirow[t]{6}{*}{$\begin{array}{l}\text { ROSO314-LEI0074 } \\
\quad(1.4-4.8)\end{array}$} & $\operatorname{DSTYK}(2.0)$ & $\begin{array}{l}\text { Dual serine/threonine and tyrosine } \\
\text { protein kinase }\end{array}$ & Development of major organs, including heart \\
\hline & & & $\operatorname{IL10}(2.5)$ & Interleukin 10 & Heart disease \\
\hline & & & PFKFB2 (2.6) & $\begin{array}{l}\text { 6-phosphofructo-2-kinase/fructose-2, } \\
\text { 6-bisphosphatase } 2\end{array}$ & $\begin{array}{l}\text { Regulates fructose-2,6-bisphosphate levels } \\
\text { in the heart }\end{array}$ \\
\hline & & & ADORA3 (3.2) & Adenosine $\mathrm{A} 3$ receptor & $\begin{array}{l}\text { Protects the ventricular heart cell against injury } \\
\text { during a subsequent exposure to ischemia }\end{array}$ \\
\hline & & & $N G F(4.0)$ & Nerve growth factor & Cardiac sympathetic innervation \\
\hline & & & PPARD (4.0) & Peroxisome proliferator - activated & Myocardial fatty acid oxidation, cardiac function \\
\hline Hematocrit & 3 & $\begin{array}{l}M C W 0040-L E I 0166 \\
\quad(103.7-105.0)\end{array}$ & $D N M T 3 A(104.2)$ & DNA Methyltransferase 3A & $\begin{array}{l}\text { Catalyzes the epigenetic modification of DNA } \\
\text { methylation, upregulation of hematopoietic stem } \\
\text { cell multipotency genes and downregulation of } \\
\text { differentiation genes }\end{array}$ \\
\hline
\end{tabular}

${ }^{a}$ No candidate genes for gizzard weight and $\%$ were found in this study

b Positions in Mb according to NCBI, Gallus_gallus-4.0. Note that the positions of markers LEPR-MCW0351 are inverted in our map compared to the genomic sequence. This may have resulted from the small distance between the two markers $(0.4 \mathrm{Mb})$

${ }^{c}$ OMIM $^{\circledR}$ (http://www.omin.org) and NCBI (http://www.ncbi.nlm.nih.gov/) databases

with different modes of action on males and females was mapped to GGA8, in the MCW0351-LEPR interval. In males, it acted in a dominant fashion with positive effects, indicating that heterozygote males had higher trait value than the midparent. In females, the same QTL presented positive additive effects, suggesting that the allele that increased trait value came from the broiler line (Table 5). The LEPR gene was selected as a candidate gene in this interval (Table 4). Disruption of the leptin signaling pathway within the heart was shown to cause left ventricular hypertrophy in mice (Raju et al. 2006). We mapped a QTL for heart weight on GGA8 in the MCW0351-LEPR interval. A QTL for total ventricular weight was previously reported in the same chromosomal region (MCW0271-LEI0044 interval) (Rabie et al. 2005). These authors indicated $T N N I 3 K$ as a positional candidate gene, a cardiac-specific kinase that mediates cell signaling to modulate cardiac response to stress (Tang et al. 2013).

Another QTL for relative heart weight mapped to GGA19 was female-specific with negative additive effects, suggesting that the allele conferring higher heart weight originated from the layer line. Eight potential candidate genes for relative heart weight were found on GGA19: MYL2, YWHAG, RASL10B, UNC45B, NEK8, SLC6A4, PIGL and AKAP10 (Table 4). Four of them seem to be more directly related to heart weight and percentage: MYL2, YWHAG, UNC45B and PIGL. In humans, 
Table 5 Quantitative trait loci with sex-specific effects

\begin{tabular}{|c|c|c|c|c|c|c|c|c|c|c|}
\hline Trait & GGA & Position (cM) & $\begin{array}{l}\text { Confidence } \\
\text { interval }\end{array}$ & $\mathrm{LRT}^{\mathrm{a}}$ & Flanking markers & Model & Sex & Additive effect (SE) & $\begin{array}{l}\text { Dominance } \\
\text { effect (SE) }\end{array}$ & PV $(\%)^{b}$ \\
\hline \multirow[t]{6}{*}{ Heart weight ${ }^{c}$} & 8 & 89.6 & $84-89.6$ & $42.41 * *$ & $M C W 0351-L E P R$ & $\mathrm{AD}$ & M & $0.00(0.11)$ & $0.73(0.17)$ & 2.92 \\
\hline & & & & & & & $\mathrm{F}$ & $0.28(0.11)$ & $0.03(0.16)$ & \\
\hline & 19 & 12 & $1-28$ & $25.86^{* *}$ & MCW0094-MCW0287 & $\mathrm{A}$ & M & $0.09(0.12)$ & & 2.39 \\
\hline & & & & & & & $\mathrm{F}$ & $-0.42(0.13)$ & & \\
\hline & 26 & 5 & $1-33$ & $28.96^{* *}$ & ROS0314-LEIOO74 & $\mathrm{AD}$ & M & $-0.10(0.14)$ & $0.18(0.24)$ & 2.76 \\
\hline & & & & & & & $\mathrm{F}$ & $0.37(0.13)$ & $-0.59(0.22)$ & \\
\hline \multirow[t]{2}{*}{ Heart (\%) } & 26 & 13 & $1-42$ & $22.57 *$ & ROS0314-LEIO074 & $\mathrm{AD}$ & M & $-0.02(0.02)$ & $0.02(0.04)$ & 1.96 \\
\hline & & & & & & & $\mathrm{F}$ & $0.06(0.02)$ & $-0.10(0.03)$ & \\
\hline \multirow[t]{2}{*}{ Hematocrit } & 3 & 273 & $263-273$ & $24.68^{*}$ & MCW0040-LEI0166 & $\mathrm{AD}$ & M & $-0.76(0.28)$ & $-1.07(0.41)$ & 2.08 \\
\hline & & & & & & & $\mathrm{F}$ & $-0.47(0.27)$ & $1.08(0.38)$ & \\
\hline
\end{tabular}

${ }^{\text {a }}$ LRT=likelihood ratio test; $\uparrow$ suggestive genome-wide; *5 \% genome-wide; **1\% genome-wide

${ }^{\mathrm{b}} \mathrm{PV}(\%)=$ percentage of the phenotypic variance explained by the QTL

${ }^{c}$ Body weight at 42 days was used as covariate in the analyses of these traits

mutations in the MYL2 gene were associated to dilated cardiomyopathy (Poetter et al. 1996). In zebrafish, knocking down $Y W H A G$ resulted in increased diameter of the heart tube (Komoike et al. 2010). UNC45B encodes a chaperone that aids in myoblast fusion and sarcomere formation of myosin isoforms required for cardiac muscle morphogenesis and contraction in zebrafish (Wohlgemuth et al. 2007). PIGL was pointed out as a strong candidate for the CHIME syndrome, which is characterized by colobomas, heart defects and other signs in humans (Ng et al. 2012).

QTLs for heart weight and percentage, also female-specific, with positive additive and negative dominance effects, were mapped in GGA26. Females that were heterozygous for these two QTLs had lighter hearts than the homozygous females. No QTL for heart weight or percentage in males was found in this study. Six positional candidate genes for heart weight and percentage were identified on GGA26: DSTYK, IL10, PFKFB2, ADORA3, NGF and PPARD (Table 4). $D S T Y K$ was suggested to have a role in the development of major organs in zebrafish, including the heart (Sanna-Cherchi et al. 2013). Knocking down this gene caused developmental defects compatible with the global loss of FGF signaling in that species. IL10 gene polymorphism was associated with lower production of this anti-inflammatory cytokine in human patients with acute myocardial infarction than in controls and older participants. Therefore, Lio et al. (2004) indicated that high production of interleukin 10 was protective for acute myocardial infarction and a determinative parameter for longevity in humans. A cultured chicken ventricular myocyte model was used to investigate the cardioprotective role of ADORA3 gene. The activation of this gene protects the ventricular heart cell against injury during a subsequent exposure to ischemia (Liang and Jacobson 1998). NGF contributes to development and maintenance of heart sympathetic innervation (Ieda et al. 2004). Deletion of PPARD in mice decreased the expression of heart fatty acid oxidation genes, leading to cardiac hypertrophy and heart failure (Cheng et al. 2004).

Finally, a QTL for hematocrit value with different effects across sexes was detected in GGA3. This QTL showed different modes of action in males and females: positive dominance effects were detected on females, suggesting that the heterozygote female had higher hematocrit value than the midparent. Negative additive effects were predominant in males, in addition to negative dominance effects, indicating that the allele that increased trait value was coming from the layer line and also that the heterozygote male had lower hematocrit than the midparent. Since higher hematocrit value was found in broilers with ascites (Luger et al. 2001), the QTL allele that increased hematocrit value could be related to ascites incidence. The fact that fast growing males are more prone to ascites than females (Moghadam et al. 2001) is in accordance with our findings. A strong potential candidate gene for hematocrit value is $D N M T 3 A$ (Table 4). It was demonstrated that this DNA methyltransferase is involved in the upregulation of hematopoietic stem cell multipotency genes and downregulation of differentiation genes in mice (Celik et al. 2015). There is indication that increased hematocrit in ascitic chickens results from enhanced, but defective erythropoiesis, leading to significant increase in immature erythrocytes (Luger et al. 2003).

The percentage of the phenotypic variance explained by the sex-different QTL varied from 1.96 to $2.92 \%$ (Table 5). These QTL with sex specific effects could help explain phenotypic differences in metabolic disorders between males and females.

In the present study, QTLs for weight of organs from the digestive tract, such as gizzard and liver, showed no specific gender effects, whereas QTL for heart weight and hematocrit 
value had sex specific effects. Different effects across sexes for relative heart weight and hematocrit may help explain higher incidence of ascites in males than in females. For gizzard \%, QTL with similar effects across sexes with various modes of action were mapped to three chromosomes, indicating that there is additive genetic variation within and nonadditive genetic variation between the lines involved in this cross for this trait. Accordingly, estimates that were obtained from $3823 \mathrm{~F}_{2}$ chickens from the reciprocal crosses between TT and CC lines (Ledur et al. 2006), revealed that heritability estimates were high for gizzard weight (0.56), intermediate for liver weight $(0.27)$ and low for heart weight $(0.11)$ and hematocrit value $(0.11)$.

Our results indicate the layer line as a possible source of alleles to increase relative heart weight, irrespective of gender. In contrast, if we consider males and females separately, QTL with additive effects on heart weight or percentage were detected on GGA8, 19 and 26 only in females. These three QTL could contribute to increase the cardiovascular capacity and should be further investigated.

A QTL allele coming from the layer line increased hematocrit value. This finding together with the fact that no QTL for lungs weight or percentage was detected, are not very promising to help mitigate the physiological problems associated with ascites in broilers. The estimate of genetic correlation of lungs weight with hematocrit value was high and negative $(-0.58)$ (Ledur et al. 2006). Therefore, increased lungs weight would be associated with lower hematocrit value and perhaps lower susceptibility to ascites. The genetic correlation of heart weight with hematocrit value in that same study was also negative, but low $(-0.12)$, indicating a weaker indirect relationship between heart weight and hematocrit value.

Overall, four novel genome-wide significant QTL with similar effects across sexes are reported here for heart weight on GGA14, for gizzard weight on GGA8, and for gizzard $\%$ on 8 and 12 . Four novel genomewide significant QTL with different effects across sexes are also reported here for heart weight on GGA19 and 26 , for heart $\%$ on GGA26 and for hematocrit value on GGA3. The 21 candidate genes retrieved from marker intervals in which QTL were mapped should be further explored in association studies with traits of interest. Likewise, mutations in these genes that were previously described in other organisms should be further investigated in chickens.

Acknowledgments The authors thank Dr Jerry Dodgson and Dr Hans H. Cheng (United States Poultry Genome Project) for primer donation. C Boschiero and K Nones received scholarships from the São Paulo Research Foundation (FAPESP), Brazil. ASAMT Moura, LFB Pinto and LL Coutinho received scholarships from the Conselho Nacional de Desenvolvimento Científico e Tecnológico (CNPq), Brazil. Financial support was provided by EMBRAPA/PRODETAB (grant number 03801/01) and FAPESP (grant number 2003/13802-6).

\section{Compliance with ethical standards}

Conflict of interest The authors declare that they have no conflict of interest.

Ethical approval All applicable international, national and institutional guidelines for the care and use of animals were followed.

\section{References}

Ambo M, Moura ASAMT, Ledur MC, Pinto LFB, Baron EE, Ruy DC, Nones K, Campos RLR, Boschiero C, Burt DW, Coutinho LL (2009) Quantitative trait loci for performance traits in a broiler $\mathrm{x}$ layer cross. Anim Genet 40:200-208

Aramaki M, Kimura T, Udaka T, Kosaki R, Mitsuhashi T, Okada Y, Takahashi T, Kosaki K (2007) Embryonic expression profile of chicken Chd7, the ortolog of the causative gene for CHARGE syndrome. Birth Defects Res Part A 79:50-57

Baron EE, Moura ASAMT, Ledur MC, Pinto LFB, Boschiero C, Ruy DC, Nones K, Zanella EL, Rosário MF, Burt DW, Coutinho LL (2010) QTL for percentage of carcass and carcass parts in a broiler $x$ layer cross. Anim Genet 42:117-124

Boschiero C, Jorge EC, Ninov K, Nones K, do Rosário MF, Coutinho LL, Ledur MC, Burt DW, Moura ASAMT (2013) Association of IGF1 and KDM5A polymorphisms with performance, fatness and carcass traits in chickens. J Appl Genet 54:103-112

Campos RLR, Nones K, Ledur MC, Moura ASAMT, Pinto LFB, Ambo M, Boschiero C, Ruy DC, Baron EE, Ninov K, Altenhofen CAB, Silva RAMS, Rosário MF, Burt DW, Coutinho LL (2009) Quantitative trait loci associated with fatness in a broiler-layer cross. Anim Genet 40:729-736

Cardoso ALSP, Tessari ENC (2003) Estudo dos parâmetros hematológicos em frangos de corte. Arq Inst Biol 70:419-424

Celik H, Mallaney C, Khotari A, Ostrander EL, Eultgen E, Martens A, Miller CA, Hundal J, Klco JM, Challen GA (2015) Enforced differentiation of Dnmt3a-null bone marrow leads to failure with c-kit mutations driving leukemic transformation. Blood 125:619-628

Cheng L, Ding G, Qin Q, Huang Y, Lewis W, He N, Evans RM, Schneider MD, Brako FA, Xiao Y, Chen YE, Yang Q (2004) Cardiomyocyte-restricted peroxisome proliferator-activated receptor-delta deletion perturbs myocardial fatty acid oxidation and leads to cardiomyopathy. Nat Med 10:1245-1250

Churchill GA, Doerge RW (1994) Empirical threshold values for quantitative trait mapping. Genetics 138:963-971

Deeb N, Lamont SJ (2002) Genetic architecture of growth and body composition in unique chicken populations. J Hered 93:107-118

Druyan S (2012) Ascites Syndrome in Broiler Chickens - A Physiological Syndrome Affected by Red Blood Cell, Blood Cell - An Overview of Studies in Hematology, Dr. Terry Moschandreou (Ed.), ISBN: 978-953-51-0753-8, InTech, doi: 10.5772/48307. http://www. intechopen.com/books/blood-cell-an-overview-of-studies-inhematology/ascites-syndrome-in-broiler-chickens-a-physiologicalsyndrome-affected-by-red-blood-cell. Accessed 23 October 2014

Druyan S, Ben-David A, Cahaner A (2007) Development of ascitesresistant and ascites-susceptible broiler lines. Poult Sci 86:811-822

Hayashi M, Iamanaka-Yoshida K, Yoshida T, Wood M, Fearns C, Tatake RJ, Lee J (2006) A crucial role of mitochondrial Hsp40 in preventing dilated cardiomyopathy. Nat Med 12:128-132 
Heallen T, Zhang M, Wang J, Binilla-Claudio M, Klysik E, Johnson RL, Martin JF (2011) Hippo pathway inhibits Wnt signaling to restrain cardiomyocyte proliferation and heart size. Science 332:458-461

Ichida F, Tsubata S, Bowles KR, Haneda N, Uese K, Miyawaki T, Dreyer WJ, Messina J, Li H, Bowles NE, Towbin JÁ (2001) Novel gene mutations in patients with left ventricular noncompaction or Barth syndrome. Circulation 103:1256-1263

Ieda M, Fukuda K, Hisaka Y, Kimura K, Kawaguchi H, Fujita J, Shimoda K, Takeshita E, Okano H, Kurihara Y, Kurihara H, Ishida J, Fukamizu A, Federoff HJ, Ogawa S (2004) Endothelin-1 regulates cardiac sympathetic innervation in the rodent heart by controlling nerve growth factor expression. J Clin Invest 113:876-884

Jaenisch FRF, Avila VS, Mazzuco H, Rosa PS, Fiorentin L (2001) Síndrome da hipertensão pulmonar: a ascite em frangos de corte. Concórdia : Embrapa Suínos e Aves (Embrapa Suínos e Aves. Circular Técnica, 27). http:www.cnpsa.embrapa.br/sgc/sgc publicacoes/cit27.pdf. Accessed 14 August 2014

Komoike Y, Fujii K, Nishimura A, Hiraki Y, Hayashidani M, Shimojima K, Nishizawa T, Higashi K, Yasukawa K, Saitsu H, Miyake N, Mizugushi T, Matsumoto N, Osawa M, Kohno Y, Higashinakagawa T, Yamamoto T (2010) Zebrafish gene knockdowns imply roles for human YWHAG in infantile spasms and cardiomegaly. Genesis 48:233-243

Krishnamoorthy S, Smith CD, Al-Rubaye AA, Erf GF, Wideman RF, Anthony NB, Rhoads DD (2014) A quantitative trait locus for ascites on chromosome 9 in broiler chicken lines. Poult Sci 93:307-317

Lander E, Kruglyak L (1995) Genetic dissection of complex traits: guidelines for interpreting and reporting linkage results. Nat Genet 11: 241-247

Ledur MC, Zanella EL, Schmidt GS, Jaenisch FRF, Silva VS, Ventura L, Coutinho LL (2000) Divergence of strains and strain crosses used to develop new reference populations for QTL studies in poultry. Proceedings of the XXI World's Poultry Congress, Montreal, Canada. CD Rom

Ledur MC, Melo CMR, Nones K, Zanella EL, Ninov K, Bonassi CA, Jaenisch FRF, Moura ASAMT, Coutinho LL, Schmidt GS (2006) Genetic and phenotypic parameters for organs, body and carcass weights, and haematocrit value, in a broiler $\mathrm{x}$ layer cross resource population. Proceedings of the 8th World Congress on Genetics Applied to Livestock Production, Belo Horizonte

Liang BT, Jacobson KA (1998) A physiological role of the adenosine $\mathrm{A}_{3}$ receptor: sustained cardioprotection. Proc Natl Acad Sci U S A 95: 6995-6999

Lio D, Candore G, Crivello A, Scola L, Colonna-Romano G, Cavallone L, Hoffman E, Caruso M, Licastro F, Caldarera CM, Branzi A, Franceschi C, Caruso C (2004) Opposite effects of interleukin 10 common gene polymorphisms in cardiovascular diseases and in successful ageing: genetic background of male centenarians is protective against coronary heart disease. J Med Genet 41:790-794

Luger D, Shinder D, Rzepakovsky V, Rusal M, Yahav S (2001) Association between weight gain, blood parameters, and thyroid hormones and the development of ascites syndrome in broiler chickens. Poult Sci 80:965-971

Luger D, Shinder D, Wolfenson D, Yahav S (2003) Erythropoiesis regulation during thedevelopment of ascites syndrome in broiler chickens: a possible role of corticosterone. J Anim Sci 81:784-790

Mangin B, Goffinet B, Rebaï A (1994) Constructing confidence intervals for QTL locations. Genetics 138:1301-1308

Moghadam HK, McMillan I, Chambers JR, Julian RJ (2001) Estimation of genetic parameters for ascites syndrome in broiler chickens. Poult Sci 80:844-848

Navarro P, Visscher PM, Knott SA, Burt DW, Hocking PM, Haley CS (2005) Mapping of quantitative trait loci affecting organ weights and blood variables in a broiler layer cross. Br Poult Sci 46:430-442

Ng BG, Hackmann K, Jones MA, Eroshkin AM, He P, Williams R, Bhide S, Cantagrel V, Gleeson JG, Paller AS, Schnur RE, Tinschert S,
Zunich J, Hedge MR, Freeze HH (2012) Mutations in the glycosylphosphatidylinositol gene PIGL cause CHIME syndrome. Am J Hum Genet 90:685-688

Nones K, Ledur MC, Ruy DC, Baron EE, Melo CMR, Moura ASAMT, Zanella EL, Burt DW, Coutinho LL (2006) Mapping QTLs on chicken chromosome1 for performance and carcass traits in a broiler $x$ layer cross. Anim Genet 37:95-100

Park H, Jacobsson L, Wahlberg P, Siegel PB, Andersson L (2006) QTL analysis of body composition and metabolic traits in an intercross between chicken lines divergently selected for growth. Physiol Genomics 25:216-223

Pavlidis HO, Balog JM, Stamps LK, Hughes JD Jr, Huff WE, Anthony NB (2007) Divergent selection for ascites incidence in chickens. Poult Sci 86:2517-2529

Pérez-Enciso M, Misztal I (2004) Qxpak: a versatile mixed model application for genetical genomics and QTL analyses. Bioinformatics 20: 2792-2798

Pinard-van der Laan M, Bertrand B, Coville J, Pitel F, Feve K, Leroux S, Legros H, Thomas A, Gourichon D, Repérant J, Rault P (2009) Microsatellite mapping of QTLs affecting resistance to coccidiosis (Eimeria tenella) in a Fayoumi $\mathrm{x}$ White Leghorn cross. BMC Genomics 10:31

Poetter K, Jiang H, Hassanzadeh S, Master SR, Chang A, Dalakas MC, Rayment I, Sellers JR, Fananapazir L, Epstein ND (1996) Mutations in either the essential or regulatory light chains of myosin are associated with a rare myopathy in human heart and skeletal muscle. Nat Genet 13:63-69

Rabie TSKM, Croojimans RPMA, Bovenhuis H, Vereijken ALJ, Veenendaal T, van der Poel JJ, Van Arendonk JAM, Pakdel A, Groenen MAM (2005) Genetic mapping of quantitative trait loci affecting susceptibility in chicken to develop pulmonary hypertension syndrome. Anim Genet 36:468-476

Raju SVY, Zheng M, Schuleri KH, Phan AC, Bedja D, Saraiva RM, Yiginer O, Vandegaer K, Gabrielson KL, O’Donell CP, Berkowitz DE, Barouch LA, Hare JM (2006) Activation of the ciliary neurotrophic factor receptor reverses left ventricular hypertrophy in leptindeficient and leptin-resistant obesity. Proc Natl Acad Sci U S A 103: 4222-4227

Sanna-Cherchi S, Sampogna RV, Papeta N, Burgess KE, Perry BJ, Choi M, Bodria M, Liu Y, Weng PL, Lozanovsky VJ, Verbitsky M, Lugani F, Sterken R, Paragas N, Caridi G, Carrea A, Dagnino M, Materna-Kiryluk A, Santamaria G, Murtas C, Ristoska-Bojkovska N, Izzi C, Kacak N, Bianco B, Giberti S, Gigante M, Piaggio G, Gesualdo L, Vukic DK, Vukojevic K, Saraga-Babic M, Gucev Z, Allegri L, Latos-Bielenska A, Casu D, State M, Scolari F, Ravazzolo R, Kiryluk K, Al-Awqati Q, D’Agati VD, Drummond IA, Tasic V, Lifton RP, Ghiggeri GM, Gharavi AG (2013) Mutations in DSTYK and dominant urinary tract malformations. New Engl J Med 369: 621-629

Schmid M, Nanda I, Hoehn H, Schartl M, Haaf T, Buerstedde JM, Arakawa H, Caldwell RB, Weigend S, Burt DW, Smith J, Griffin DK, Masabanda JS, Groenen MA, Crooijmans RP, Vignal A, Fillon V, Morisson M, Pitel F, Vignoles M, Garrigues A, Gellin J, Rodionov AV, Galkina SA, Lukina NA, Ben-Ari G, Blum S, Hillel J, Twito T, Lavi U, David L, Feldman MW, Delany ME, Conley CA, Fowler VM, Hedges SB, Godbout R, Katyal S, Smith C, Hudson Q, Sinclair A, Mizuno S (2005) Second report on chicken genes and chromosomes 2005. Cytogenet Genome Res 109:415-479

Sorensen P, Lund MS, Guldbrandtsen B, Jensen J, Sorensen D (2003) A comparison of bivariate and univariate QTL mapping in livestock populations. Genet Sel Evol 35:605-622

Tang H, Xiao K, Mao L, Rockman HA, Marchuk DA (2013) Overexpression of TNNI3K, a cardiac-specific MAPKKK, promotes cardiac dysfunction. J Mol Cell Cardiol 54:101-111 
Vallaster M, Vallaster CD, Wu SM (2012) Epigenetic mechanisms in cardiac development and disease. Acta Biochim Biophys Sin 44:92-102

Vissers LELM, van Ravenswaaij CMA, Admiraal R, Hurst JA, de Vries BBA, Janssen IM, van der Vliet WA, Huys EHLPG, de Jong PJ, Hamel BCJ, Schoenmakers EFPM, Brunner HG, Veltman JA, van Kessel AG (2004) Mutations in a new member of the chromodomain gene family cause CHARGE syndrome. Nat Genet 36:955-957

Wideman RF Jr, French H (2000) Ascites resistance of progeny from broiler breeders selected for two generations using chronic unilateral pulmonary artery occlusion. Poult Sci 79: 396-401

Wohlgemuth SL, Crawford BD, Pilgrim DB (2007) The myosin cochaperone UNC-45 is required for skeletal and cardiac muscle function in zebrafish. Dev Biol 303:483-492

Zhou H, Deeb N, Evock-Clover CM, Ashwell CM, Lamont SJ (2006) Genome-wide linkage analysis to identify chromosomal regions affecting phenotypic traits in the chicken. II. Body composition. Poult Sci 85:1712-1721 